\title{
Improve Student Learning Outcomes in Science Grade IV Elementary Schools With A Google Meet Assisted Project Based Learning (PjBL) Learning Model
}

\author{
Prestiyawati Asa \\ SDN 1 Wonobodro \\ prestiyawati@gmail.com
}

\section{Article History}

accepted 14/11/2020

\begin{abstract}
The purpose of this research was to improve student learning outcomes in science grade IV elementary schools with a Google meet assisted Project Based Learning (PjBL) learning model.Classroom Action Research (PTK) with three cycles, with each cycle consisting of two meetings. The stages of each cycle are planning, implementing, observing and reflecting. Each meeting is carried out a pre test and post test to determine the progress of students. In the first cycle the students who completed after carrying out the post test were $62,50 \mathrm{n} \%$. In the second cycle students who completed after carrying out the post test were $87,50 \%$. These results indicate that the Project Based Learning (PjBL) learning model can improve student learning outcomes, especially grade IV science at SDN 1 Wonobodro.
\end{abstract}

Keywords: Learning outcomes, project based learning, science

\begin{abstract}
Abstrak
Tujuan dari penelitian ini adalah untuk meningkatkan hasil belajar siswa kelas IV IPA SD dengan model pembelajaran Google Meet Assisted Project Based Learning (PjBL). Penelitian Tindakan Kelas (PTK) dengan tiga siklus, dengan setiap siklus terdiri dari dua pertemuan. Tahapan setiap siklus adalah perencanaan, pelaksanaan, observasi dan refleksi. Setiap pertemuan dilakukan pre test dan post test untuk mengetahui kemajuan siswa. Pada siklus I siswa yang tuntas setelah melaksanakan post test sebanyak $62,50 \mathrm{n} \%$. Pada siklus II siswa yang tuntas setelah melaksanakan post test sebanyak $87,50 \%$. Hasil tersebut menunjukkan bahwa model pembelajaran Project Based Learning (PjBL) dapat meningkatkan hasil belajar siswa khususnya kelas IV IPA di SDN 1 Wonobodro.
\end{abstract}

Kata kunci: Hasil belajar, project based learning, IPA 


\section{PENDAHULUAN}

Dalam proses belajar mengajar peserta didik diharapkan adanya suasana pembelajaran yang akan mampu mengekplorasi kemampuan peserta didik secara aktif. Namun pada kenyataannya di lapangan suasana pembelajaran sudah cukup baik dan kondusif, banyak peserta didik yang aktif, hanya saja guru belum sepenuhnya mengcover semua peserta didik yang aktif, mengingat waktu pembelajaran yang ditentukan. Peran guru dalam memperingatkan peserta didik yang aktif sendiri diluar konteks pelajaran cukup membantu suasana menjadi kondusif lagi, namun itu belum cukup banyak membantu peserta didik menjadi fokus dalam mengikuti pembelajaran. Dari data daftar nilai analisis, perbaikan, pengayaan, pengolahan dan pelaporan hasil belajar tahun ajaran 2019-2020 menunjukkan banyaknya peserta didik yang memiliki nilai rendah, khususnya pada nilai hasil ulangan harian pertama,dari 24 peserta didik ada 15 peserta didik yang mendapatkan nilai< 65 dari KKM 70 . Salah satu model pembelajaran yang dapat diterapkan yaitu model Problem Based Learning (Pembelajaran Berbasis Masalah).

Menurut Brunner dalam Sugandi (2007:36) ada empat hal pokok penting yang perlu diperhatikan yaitu peranan pengalaman struktur pengetahuan, kesiapan mempelajari sesuatu, intuisi dan cara membangkitkan motivasi belajar. Guru dituntut untuk bisa membawa peserta didik ke dalam dunia yang menyenangkan di dalam pembelajaran. Peserta didik yang merasa nyaman dan senang, maka akan berani untuk aktif dan akan mempunyai motivasi lebih untuk terus belajar. Peserta didik yang mempunyai motviasi lebih untuk belajar biasanya akan mendapatkan hasil belajar yang baik. Guru sebagai pemegang proses pembelajaran harus bisa menyajikan hal terbaik. Model pembelajaran yang digunakan haruslah sesuai dengan materi yang sedang diajarkan, karena tidak semua model pembelajaran dapat digunakan untuk semua materi. Pemilihan model pembelajaran akan mendukung hasil pembelajaran yang akan dicapai. Semua muatan pelajaran membutuhkan penerapan model pembelajaran.

PBL merupakan suatu model pembelajaran yang titik tolak utamanya adalah masalah dan cara penyelesaiannya. Model pembelajaran ini menekankan pada pemecahan masalah yang diberikan guru berdasarkan informasi yang peserta didik miliki khususnya untuk pembelajaran IPA dimana pembelajaran IPA menuntut suatu keterampilan proses peserta didik untuk memehami secara detail karena pembelajaran IPA adalah suatu pembelajaran yang mengkaitkan antara lingkungan sekitar peserta didik dengan materi yang ada. Melihat proses pembelajaran yang cukup kondusif dan baik, respon peserta didik yang baik dan aktif namun hasil belajar peserta didik masih cukup rendah dan bisa ditingkatkan, maka peneliti mencoba memperbaiki model pembelajaran yang diterapkan dalam pembelajaran IPA di kelas IV SD Negeri Wonobodro 01 Kecamatan Blado dengan cara mengadakan Penelitian Tindakan Kelas (PTK) dengan menggunakan metode Problem Based Learning (Pembelajaran Berbasis Masalah) diharapkan dapat meningkatkan hasil belajar peserta didik dalam mata pelajaran IPA.

Berdasarkan kajian teori dan kerangka berpikir seperti yang sudah diungkapkan di atas, hipotesis tindakan ini adalah penggunaan model pembelajaran PBL dapat meningkatkan hasil belajar IPA peserta didik kelas IV SD Negeri Wonobodro 01 Kecamatan Blado Tahun Ajaran 2020/2021.

Menurut Sujana (2009: 3) hasil belajar peserta didik pada hakekatnya adalah perubahan tingkah laku. Tingkah laku sebagai hasil belajar dalam pengertian yang luas mencakup bidang kognitif, afektif dan psikomotoris. Selain perubahan tingkah laku, jika di sekolah hasil belajar biasanya dinilai dengan angka. Peserta didik akan mendapat nilai yang akan menggambarkan keberhasilan dalam belajar. Pembelajaran IPA pada penelitian ini menggunakan model pembelajaran Project Based Learning (PjBL) 
merupakan salah satu model pembelajaran yang berpijak pada teori belajar konstruktivistik. Driscoll dalam Miyarso (2019: 120) menyatakan prinsip-prinsip pembelajaran kontruktivistik adalah melibatkan pebelajar dalam aktivitas nyata, negosiasi sosial dalam proses belajar, kolaboratif dan pengkajian multiperspektif, dukungan menentukan tujuan dan mengatur proses belajar, dan dorongan merefleksikan apa dan bagaimana sesuatu dipelajari. Menurut Surya, dkk (2018) Model pembelajaran Project Based Learning (PjBL) merupakan pembelajaran yang inovatif yang berpusat kepada siswa (Student Centered) dan menempatkan guru sebagai motivator dan fasilitator, dimana dalam hal ini siswa diberi peluang untuk bekerja secara otonom mengkonstruksi belajarnya. Model pembelajaran berbasis proyek (Project Based Learning) siswa merancang sebuah masalah dan mencari penyelesaiannya sendiri, sehingga mampu meningkatkan kreatifitas siswa untuk memunculkan penyelesaiannya sendiri membuat kegiatan pembelajaran lebih bermakna sehingga teringat.

Menurut Nurfitriyanti (2016) project based learning adalah pembelajaran yang memerlukan jangka waktu panjang, menitikberatkan pada aktifitas peserta didik untuk dapat memahami suatu konsep atau prinsip dengan melakukan investigasi secara mendalam tentang suatu masalah dan mencari solusi yang relevan serta diimplementasikan dalam pengerjaan proyek, sehingga peserta didik mengalami proses pembelajaran yang bermakna dengan membangun pengetahuannya sendiri.Penekanan pembelajaran terletak pada aktifitas peserta didik untuk memecahkan masalah dengan menerapkan keterampilan meneliti, menganalisis, membuat, sampai dengan mempresentasikan produk pembelajaran berdasarkan pengalaman nyata. Metode pembelajaran project based learning memperkenankan peserta didik untuk dapat bekerja mandiri maupun dengan cara berkelompok dalam menghasilkan hasil proyeknya yang bersumber dari masalah kehidupan sehari-hari. Langkah dalam model pembelajaran Project Based Learning sangat memerlukan kemampuan berpikir kreatif siswa. Suatu proyek yang ideal adalah merupakan sesuatu yang baru dan asli, namun hal ini tidaklah mutlak bagi siswa. Dapat pula siswa bekerja dalam suatu proyek yang bertolak dari ide orang lain, tetapi kemudian mengadakan modifikasi dari dasar pemikiran (Efrimal, dkk, 2017).

\section{METODE}

Penelitian ini adalah penelitian tindakan kelas (Classroom Action Research) dengan menerapkan model pembelajaran Project Based Learning (PjBL). Menurut Kurt Lewin dalam Kunandar (2011: 42) penelitian tindakan kelas ini terdiri dari empat tahapan dasar yaitu perencanaan (planning), pelaksanaan (acting), pengamatan (observing) dan refleksi (reflecting). Analisis penelitian ini adalah analisis deskriptif kuantitafif kualitatif dimana dalam penelitian ini selain penyajian hasil berupa data maupun angka peneliti juga menentukan bagaimana cara pengolahan hasil penelitian yakni dengan membuat analisisnya dengan menerapkan model penelitian Project Based Learning (PjBL). Penelitian ini dilaksanakan pada peserta didik kelas IV SD Negeri 01 Wonobodro Tahun Pelajaran 2020/2021 selama dua siklus secara daring menggunakan aplikasi Google meet dengan satu pertemuan disetiap siklusnya.

Siklus 1 dilaksanakan pada tanggal 16 November 2020. Siklus II dilaksanakan pada tanggal 23 Desember 2020. Teknik pengumpulan data yang dilakukan dengan observasi dan tes, baik pre test maupun post test. Observasi meliputi observasi keterlaksanaan model pembelajaran PjBL, sikap peserta didik dan keterampilan. Untuk hasil belajar menggunakan tes melalui Google form dan Kahoot

HASIL DAN PEMBAHASAN 
Pada siklus I pembelajaran dilaksanakan selama dua pertemuan, setiap pertemuan diadakan pre test dan post test. Untuk mengetahui perkembangan peserta didik selama pembelajaran. Siklus I membahas materi tentang rantai makanan, berupa komponen dalam rantai makanan dan permasalahan jika salah satu populasi punah dalam rantai makanan. Pembelajaran dengan model PjBL dilaksanakan dengan 6 langkah $\mathrm{PjBL}$ secara berurutan mulai dari menentukan pertanyaan mendasar, merancang proyek, menyusun jadwal, memantau proses proyek, penilaian hasil dan evaluasi pengalaman. Proyek yang dibuat peserta didik adalah menyusun rantai makanan dengan gambar yang tepat.

Berikut ini adalah hasil belajar peserta didik padasiklus I yang bisa dilihat pada tabel berikut.

Hasil penelitian yang terdiri dari perencanaan, pelaksanaan dan pengamatan, dan refleksi perencanaan Materi yang digunakan dalam melaksanakan penelitian IPA kelas IV adalah upaya kelestarian sumber daya alam.

Rancangan tindakan pada siklus I terdiri dari dua pertemuan, pertemuan pertama guru membagi siswa dalam beberapa kelompok, kemudian memberikan permasalahan yang harus diselesaikan oleh masing-masing kelompok, guru mendampingi, membantu dan memberikan pengarahankepada siswa dalam berdiskusi mencari dan menyelesaikan permasalahan untuk dilaporkan pada kegiatan selanjutnya yaitu presentasi. Pertemuan kedua ini guru membimbing siswa untuk melakukan presentasi dari hasil diskusi kelompok tentang materi IPA yang sudah siswa dapatkan sebelumnya, guru besesama siswa saling bertukar pendapat dan pengetahuan untuk mendapatkan jawaban yang tepat dan benar

Pelaksanaan: peneliti melaksanakan penelitian siklus pertama belum sesuai dengan perencanaan, hasil dari penelitian siklus pertama.

\section{Siklus 1}

Tabel Rekapitulasi Hasil Tes siklus 1 dalam Mata Pelajaran IPA peserta didik kelas IV SD Negeri Wonobodro 01 Kecamatan Blado

\begin{tabular}{ccc}
\hline NILAI & JUMLAH SISWA & POSENTASE \\
\hline$<\mathbf{7 0}$ & 9 & 37,50 \\
\hline $\mathbf{7 0}$ & 7 & 29,16 \\
\hline $\mathbf{8 0}$ & 5 & 20,83 \\
\hline $\mathbf{9 0}$ & 3 & 12,50 \\
\hline $\mathbf{1 0 0}$ & 0 & 0 \\
\hline
\end{tabular}

\begin{tabular}{ccc}
\hline Kriteria & \multicolumn{2}{c}{ Siklus 1 } \\
\cline { 2 - 3 } keberhasilan & $\begin{array}{c}\text { jumlah } \\
\text { siswa }\end{array}$ & Persentase(\%) \\
\hline Nilai $<70$ & 9 & $\mathbf{3 7 , 5 0}$ \\
Nilai $\geq \mathbf{7 0}$ & 15 & $\mathbf{6 2 , 5 0}$ \\
\hline Jumlah & $\mathbf{2 4}$ & $\mathbf{1 0 0}$ \\
\hline
\end{tabular}




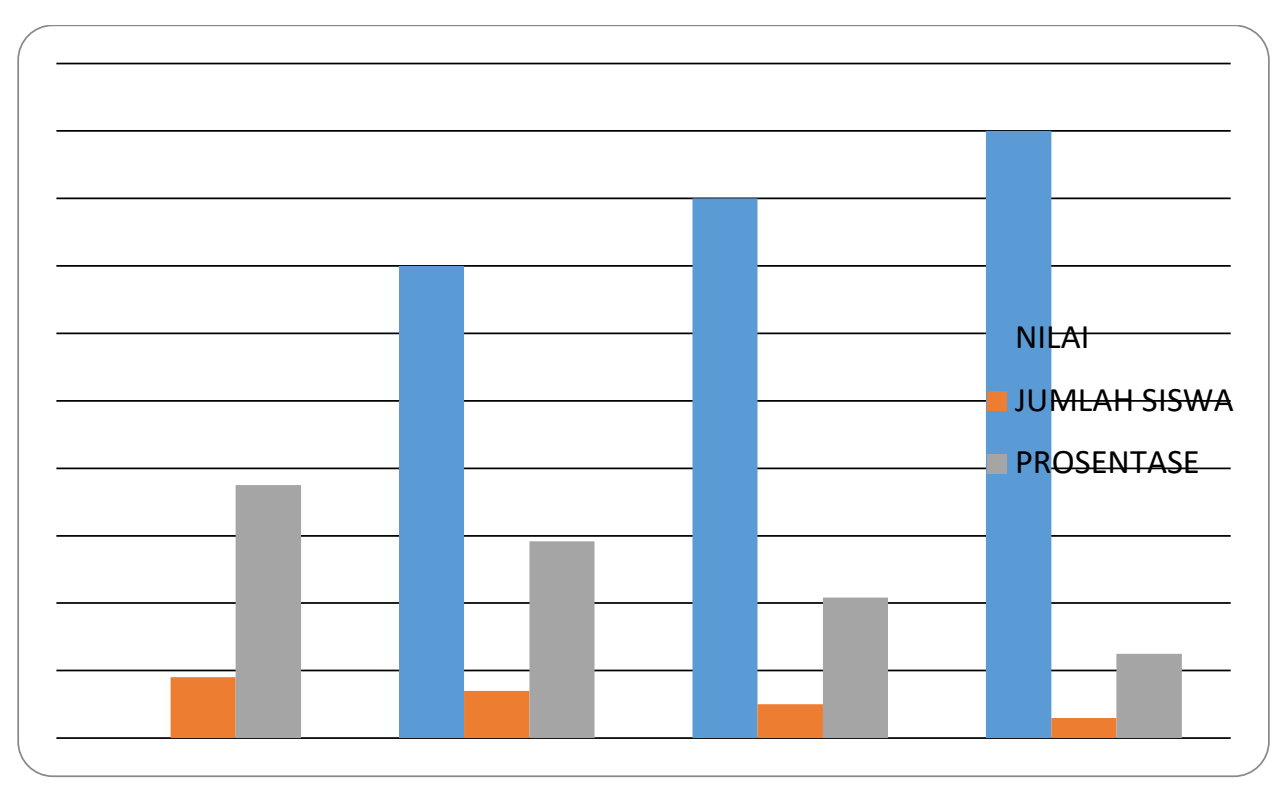

\section{Gambar Siklus 2}

Tabel 2. Rekapitulasi Hasil Tes siklus 2 dalam Mata Pelajaran IPA peserta didik kelas IV SD Negeri Wonobodro 01 Kecamatan Blado

\begin{tabular}{ccc}
\hline NILAI & JUMLAH SISWA & POSENTASE \\
\hline$<\mathbf{7 0}$ & 3 & 12,50 \\
\hline $\mathbf{7 0}$ & 5 & 20,83 \\
\hline $\mathbf{8 0}$ & 9 & 37,50 \\
\hline $\mathbf{9 0}$ & 5 & 20,83 \\
\hline $\mathbf{1 0 0}$ & 2 & 8,33 \\
\hline
\end{tabular}

\begin{tabular}{ccc}
\hline $\begin{array}{l}\text { Kriteria } \\
\text { keberhasilan }\end{array}$ & $\begin{array}{c}\text { jumlah } \\
\text { siswa }\end{array}$ & $\begin{array}{c}\text { Siklus II } \\
\text { Persentase(\%) }\end{array}$ \\
\hline Nilai $<70$ & 3 & $\mathbf{1 2 , 5 0}$ \\
Nilai $\geq \mathbf{7 0}$ & 21 & $\mathbf{8 7 , 5 0}$ \\
\hline Jumlah & $\mathbf{2 4}$ & $\mathbf{1 0 0}$ \\
\hline
\end{tabular}




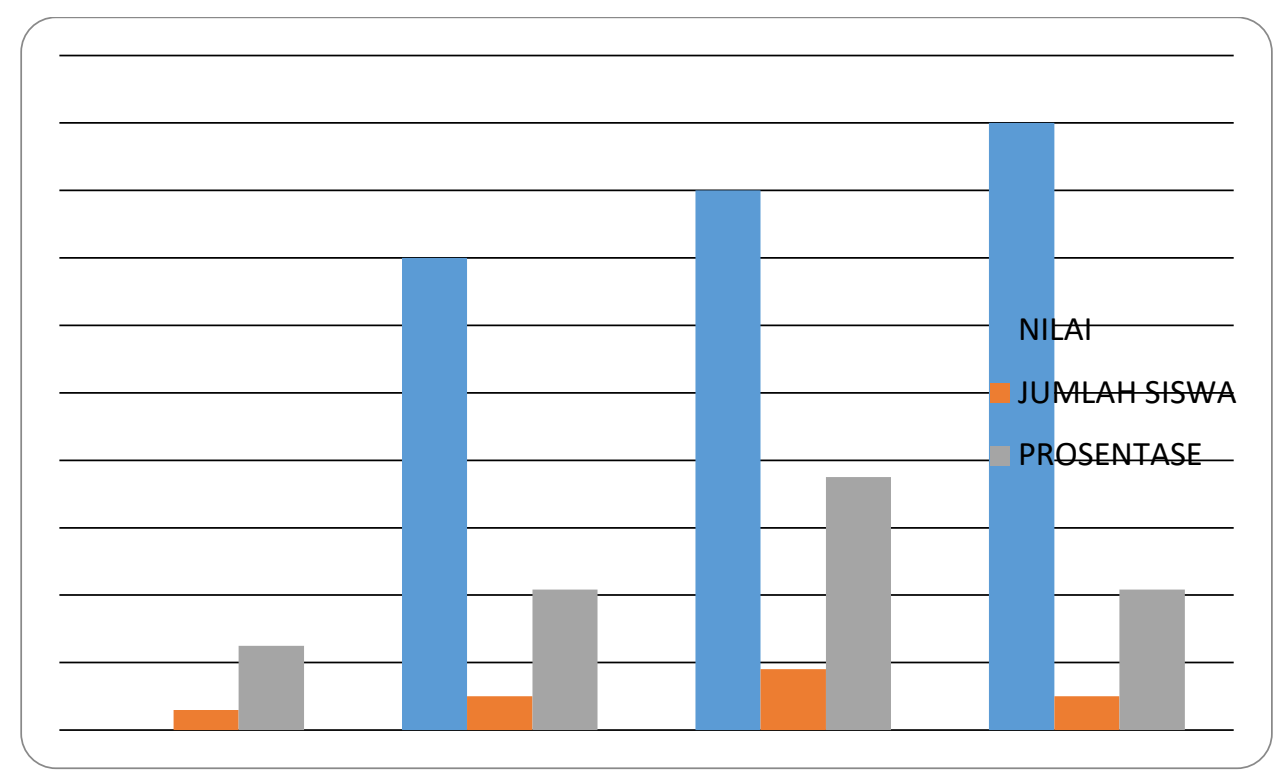

Gambar 2. Perbandingan Siklus I dan Siklus II

Berdasarkan hasil siklus I dan II dapat disimpulkan bahwa dengan model problem based learning dapat meningkatkan cara berfikir kritis peserta didik kelas IV SD Negeri Wonobodro 01 Kecamatan Blado Kabupaten Batang.

\section{SIMPULAN}

Penerapan model pembelajaran Project Based Learning (PjBL) dapat meningkatkan hasil belajar peserta didik Kelas $V$ pada mupel IPA materi rantai makanan. Peningkatan yang terjadi karena adanya kesan pembelajaran yang mendalam dari peserta didik tehadap materi yang diajarkan melalui setiap proyek yang dibuat. Peserta didik akan selalu teringat akan materi yang diajarkan dikarenakan mereka menemukan dan membangun sendiri pengetahuan mereka pada saatmembuat proyek yang sudah disepakati. Berdasarkan penelitian yang telah dilaksanakan salah satu model pembelajaran yang harus dikuasai guru adalah $\mathrm{PjBL}$ karena model ini sangat cocok digunakan dalam keadaan pandemi seperti ini, apalagi dalam kondisi belajar dari rumah. Peserta didik akan membangun pengetahuannya sendiri dengan proyek yang sudah disepakati. Guru bisa memantau proses selama proyek dilaksanakan dengan bekerja sama dengan orang tua.

\section{DAFTAR PUSTAKA}

Abiddin Nata. (2009). Perspektif Islam Tentang Strategi Pembelajaran.Jakarta: Prenada Media. Amir, M. Taufiq. (2009).

Inovasi Pendidikan Melalui Problem Based Learning. Jakarta: Kencana Prenada Media Group. Ardana, Komang, Ni Wayan Mujiati, dan Anak Agung Ayu Sriathi. (2009).

Perilaku Keorganisasian. Penerbit Graha Ilmu. Jakarta. Arnyana, Ida Bagus Putu. (2006).

Perencanaan dan Desain Model-model pembelajaran. Singaraja. Jurusan Pendidikan Biologi. FPMIPA UNDIKSHA. Arum Pramityasari dan Siti Maisaroh. (2015). berjudul Pengaruh Model Pembelajaran Mind Mapping Dan Problem Based Learning Terhadap Minat Belajar IPS Peserta didik Kelas IV SD Kebonagung Imogiri Bantul Yogyakarta Tahun Pelajaran 2013/2014. Jurnal PGSD Indonesia ISSN 2443-1656 Vol. 1 No. 1 April 2015. Depdiknas. (2006). 
Kurikulum Tingkat Satuan Pendidikan. Jakarta: Depdiknas. Dimyati dan Mudjiono. (2006). Belajar dan Pembelajaran. Jakarta: Rineka Cipta. Hamzah B Uno. (2010). Perencanaan Pembelajaran. Jakarta: Bumi Aksara. Haris Muhammad Abdul.(2013).

Pengaruh Penerapan Model Problem Based Learning Terhadap Kemampuan Memecahkan Masalah Dalam Pembelajaran IImu Pengetahuan Sosial. Skripsi. S1. PGSD. Universitas Negeri Yogyakarta. http://eprints.uny.ac.id/id/eprint/15968. Hergenhahn, B.R., dan Olson, M.Hg. (2008). Theories Of Learning (Teori Belajar). Jakarta: Kencana. I Wayan Santyasa dan Sukadi. (2009). Model-model Pembelajaran Inovatif.

Makalah disajikan dalam Pendidikan dan Latihan Peofesi Guru (PLPG): UNDIKSHA. Singaraja 7-17 September 2009. Maslichah Asy'ari. (2006).

Sugandi, A. 2007. Teori Pembelajaran. Semarang: UNNES Press. Surya. A.P, dkk (2018). Penerapan Model Pembelajaran Project Based Learning (PjBL) untuk Meningkatkan Hasil Belajar dan Kreativitas Siswa Kelas III SD Negeri Sidojero Lor 01 Salatiga. Jurnal Pesona Dasar, 6(1), 51-54. 